\title{
Public Policies for Higher Education Systems in 10 ASEAN Associate Countries
}

\author{
M. Syahruddin1, Rosmayati, Darma Bakti, and Yusuf L. Henuk2² \\ ${ }^{1}$ Medan State Polytechnic, Medan, Indonesia \\ ${ }^{2}$ Faculty of Agriculture, University of Sumatera Utara, Medan 20155 Indonesia \\ *Corresponding/presenting Author: yusufhenuk62@live.com ${ }^{2}$
}

\begin{abstract}
The Association of Southeast Asian Nations (ASEAN) was established on the $8^{\text {th }}$ August, 1967 to promote economic development, technology, and competitive advantage in the region. The founding countries of ASEAN are Indonesia, Thailand, Malaysia, Singapore, and the Philippines. They were subsequently joined by Brunei Darussalam in 1984, Vietnam in 1995, Myanmar in 1997, Laos in 1997, and Cambodia in 1999. In its 2007 Economic Blueprint, an ASEAN first introduced its goal of achieving closer economic integration among its 10 member states by the establishment of the ASEAN Economic Community (AEC) by 31 December 2015. The AEC under the slogan of "one vision, one identity, and one community" is based on four main objectives: (1). Building a free trade and service area, including freedom of investment, labor, and capital; (2). Creating competitive advantage, including e-ASEAN development, and tax and competitive policy development; (3). Sustainable economic development, including support of small and medium enterprises (SMEs); (4). Economic integration with the rest of the world, including Free Trade Area (FTA) planning with other countries, and production networks. ASEAN now has focused their more attention on education sector. In conclusion, public policies for the higher education systems in the ASEAN countries is various; therefore students involved in the intra - regional movement may face many problems in terms of cultural diversity, language and communication barrier, instructional practices and curriculum incomparability. Public policies for the higher education systems in 5 ASEAN associate countries are expired and the half of them are still valid, namely Malaysia, Myanmar, Philippines, Thailand and Vietnam.
\end{abstract}

Keyword: public policy, higher education, 10 ASEAN associate countries, ASEAN Economic Community

\section{INTRODUCTION}

The Association of Southeast Asian Nations (ASEAN) was established on the $8^{\text {th }}$ August, 1967 to promote economic development, technology, and competitive advantage in the region. The founding countries of ASEAN are Indonesia, Thailand, Malaysia, Singapore, and the Philippines (ASEAN Secretariat, 1967). They were subsequently joined by Brunei Darussalam in 1984, Vietnam in 1995, Myanmar in 1997, Laos in 1997, and Cambodia in 1999. In its 2007 Economic Blueprint (ASEAN Secretariat, 2009), an ASEAN first introduced its goal of achieving closer economic integration among its 10 member states (Map 1) by the establishment of the AEC by 31 December 2015. There are three main dimensions of ASEAN, namely the ASEAN
Political-Security Community, the AEC, and the ASEAN Socio-Cultural Community. With the establishment of the AEC in 2015, it is hoped that the ASEAN member countries will become a single market and production network. The AEC under the slogan of "one vision, one identity, and one community" is based on four main pillars: (1) Single Market and Production Base: the region as a whole must become a single market and production base to produce and commercialize goods and services anywhere in ASEAN; (2) Competitive Economic Region: the region must emphasize on the competitiveness of its production and capacity for export, as well as the free competition inside of its frontiers; (3) Equitable Economic Development: to receive the benefits of the AEC, the people and businesses of ASEAN must be engaged into the integration process of the 
AEC; and (4) ASEAN's integration into the globalized economy: ASEAN must not be isolated but an integrated part of the global economy (Figure 1). Through the implementation of these four pillars for economic integration, stability, competitive, and dynamism, ASEAN is bound to realize the principles of an Economic Community, inspired by the model of the European Union (Anonymous, 2015). Current demographic and macroeconomic of 10 ASEAN member countries have briefly summarized by Anonymous (2015) and Holloway et al. (2015, Figure 2).

\section{Single Market \&}

Production

Base

4 pillars of the ASEAN

Equitable Economic Development

\section{Competitive Economic Region}

\section{ASEAN Empowering business in Southeast Asia - aseanup.com}

Figure 1. 4 pillars of the AEC.

ASEAN now has focused their attention much on education sector. Mainly, they aim to achieve productivity in work force and skilled labors in targeting the economic indicators of the region. Some countries in the region experience the imbalance between the skilled labors they produced through their education system and with the development of the industry sector. Improvement of infrastructure, teaching skills and technical skills of the students has become the major problems in education sector. In this connection many government in the region have to focus much on private participation (Sagarik and Kumari, 2014). 


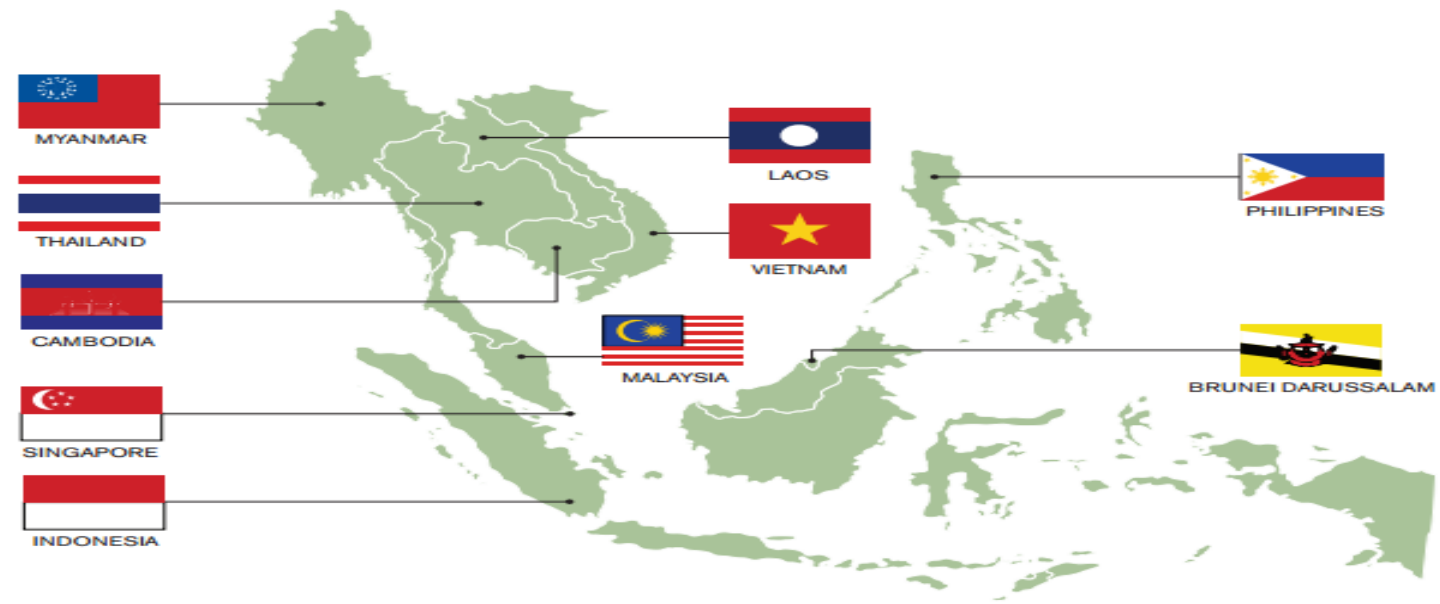

Map 1. 10 member countries of ASEAN

\section{ASEAN: State of the Nations}

\begin{tabular}{|c|c|c|c|}
\hline & 1990 & 2000 & 2012 \\
\hline $\begin{array}{l}\text { ASEAN } \\
\text { Member States }\end{array}$ & $\begin{array}{c}\text { Brunei } \\
\text { Darussalam } \\
\text { Indonesia } \\
\text { Malaysia } \\
\text { Philippines } \\
\text { Singapore } \\
\text { Thailand }\end{array}$ & $\begin{array}{l}\text { Brunei } \\
\text { Danussalam } \\
\text { Cambodia } \\
\text { Lao DPR } \\
\text { Indonesia } \\
\text { Malaysia } \\
\text { Myanmar } \\
\text { Philippines } \\
\text { Singapore } \\
\text { Thailand } \\
\text { Viet Nam }\end{array}$ & $\begin{array}{l}\text { Brunei } \\
\text { Darussalam } \\
\text { Cambodia } \\
\text { Lao DPR } \\
\text { Indonesia } \\
\text { Malaysia } \\
\text { Myanmar } \\
\text { Philippines } \\
\text { Singapore } \\
\text { Thailand } \\
\text { Viet Nam }\end{array}$ \\
\hline Total GDP (USS Billion) & 334.1 & 606.4 & $2,311.3$ \\
\hline Avg GDP per capita (USS)! & 760.9 & $1,172.4$ & $3,748.4$ \\
\hline Total Trade (USS Bilion). & 306.4 & 759.1 & $2,476.4$ \\
\hline Intra-Trade (USS Billion) & 144.1 & 166.8 & 602.0 \\
\hline FDI Inflows (USS Billion) & 12.8 & 21.8 & 110.3 \\
\hline $\begin{array}{l}\text { FDI Inflows } \\
\text { (\% of Clobal Inflows) }\end{array}$ & 6.2 & 1.6 & 8.2 \\
\hline Population (Million) & 317.2 & 517.3 & 617.2 \\
\hline $\begin{array}{l}\text { Poverty Rate' } \\
\text { (\% Population Living } \\
\text { Below USS1.25 PPP } \\
\text { per capita per day) }\end{array}$ & 45.0 & 33.0 & $15.3^{3}$ \\
\hline $\begin{array}{l}\text { Infarnt Mortality Rate } \\
\text { (per 1,000 live births) }\end{array}$ & 27.3 & 35.9 & 22.4 \\
\hline
\end{tabular}

Figure 2a. Current macroeconomic in 10 ASEAN associate countries. 


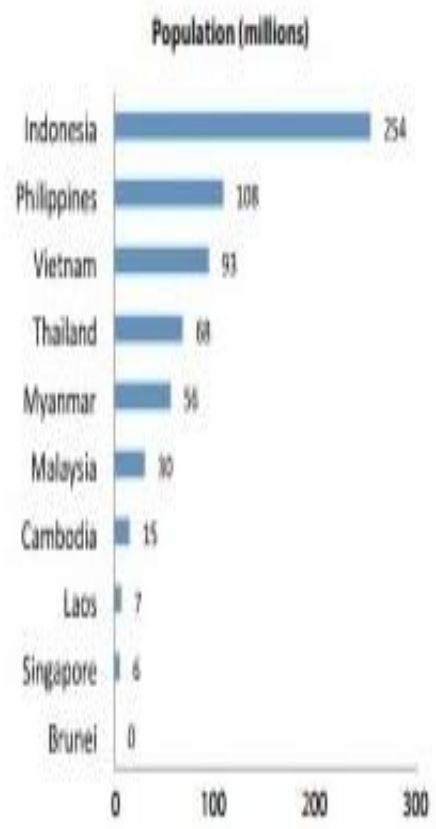

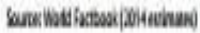

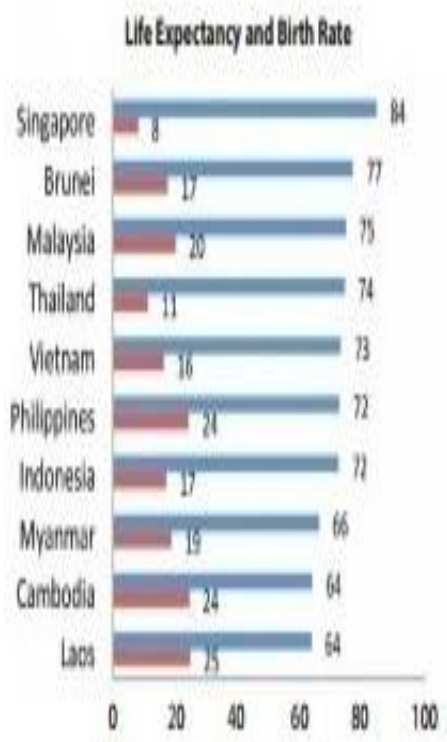

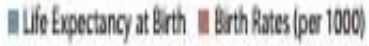
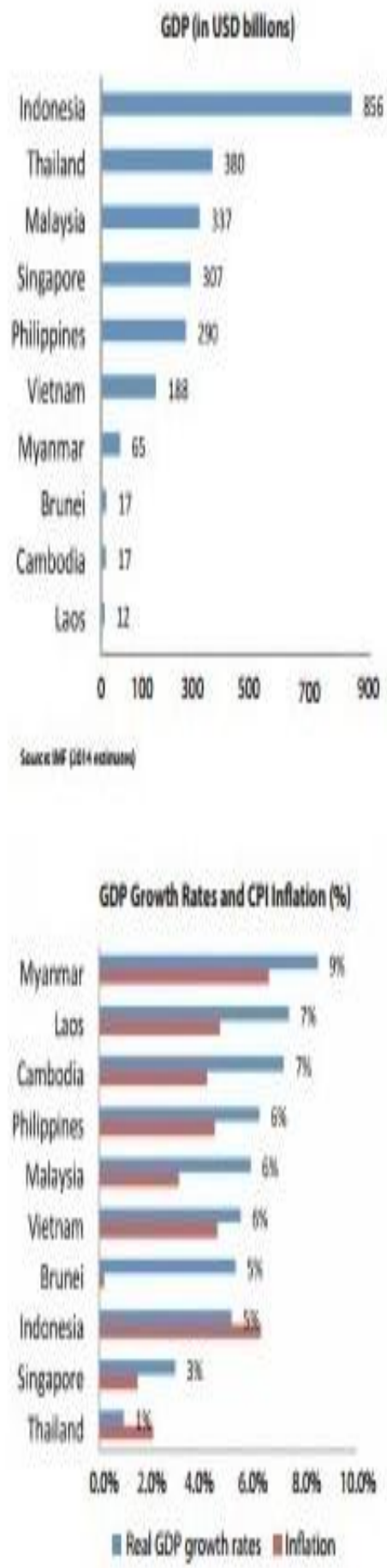
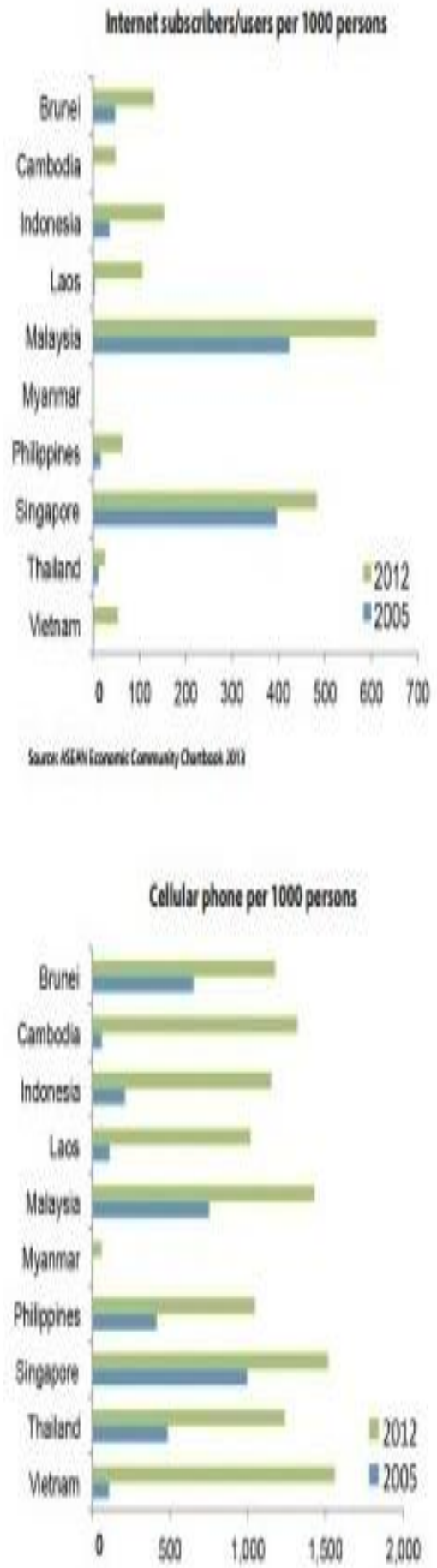

Figure 2b. Current demographic and macroeconomic of 10 ASEAN associate countries.

Basically, the AEC Blueprint (ASEAN production base is built on five core principles Secretariat, 2009), an ASEAN single market and of the ASEAN single market and production 
base: (i) free flow of goods, (ii) free flow of services, (iii) free flow of investment, (iv) free flow of capital, and (v) free flow of skilled labor. In pursuit of the last two pillars of AEC objective (building a free trade and service area, including freedom of investment, labor, and capital), the member countries entered into the ASEAN Framework Agreement on Services (AFAS) as well as the Mutual Recognition Arrangement (MRA) that will regulate the free flow of services in the member countries. Eight specific professions will be free to work within ASEAN member countries after 2015. The eight professions are Engineering, Nursing, Medicine, Dentistry, Architecture, Surveying, Tourism and Accounting (Suttipun, 2014). With regard to these pillars, one of the objectives of the AEC, as stipulated on Article 1 Paragraph 10 of the ASEAN Charter, is to develop human resources through closer cooperation in education and lifelong learning, for the empowerment of the people of ASEAN and for the strengthening of the ASEAN Community (ASEAN Secretariat, 2008).

In general, higher education systems across ASEAN face a similar set of seven overarching global challenges as follows: (a) Maintaining and improving education quality, even in the face of serious financial, income inequalities, cultural and demographics constraints; (b) Improving the relevance of curriculum and instruction at a time of rapid change in labor market needs due to shifting production and consumption, globalization and global system disruptions; (c) Increasing and better utilizing the financial resources available to higher education; and (d) Increasing of private higher education institutions and balancing the continued expansion of access to higher education with greater attention to equity and to the need to raise quality through regulations; (e) Catering to the knowledge and skills development of marginalized and displaced through informal learning (f) Minimizing Corruption and Politicization of Education (g) Interdependent of dynamics overwhelming national policy capabilities, in finance, migration, government revenues, and education (Shawyun, 2014). This paper reviews literature which identifies public policies for higher education systems in 10 ASEAN associate

\section{PUBLIC POLICIES FOR HIGHER EDUCATION SYSTEMS IN 10 ASEAN ASSOCIATE COUNTRIES}

"Education lies at the core of AEC's development process, creating knowledge based society and contributing to the enhancement of ASEAN competitiveness". National government of each ASEAN member country understands that education underpins the development of the AEC; higher education systems is valuable for individual and beneficial to the economy. Therefore, each government has taken key steps in the development of their higher educational policies (ASEAN Secretariat, 2014 - Table 1). However, public policies for the higher education systems in the ASEAN countries is various; therefore students involved in the intra - regional movement may face many problems in terms of cultural diversity, language and communication barrier, instructional practices and curriculum incomparability (Pyakurel, 2014).

Pyakurel (2014) has also conducted interviews with several business executives and professors from different companies and universities in order to understand their opinions about AEC and its effects on higher education and the job market. She concluded that most of the respondents agreed that university education system among ASEAN countries is diverse. They also agreed that such diversity in the university system could pose challenge to the job market after the implementation of AEC in 2015. They agreed that there is a lack of standard to verify the skills of the graduates because as there is no uniformity in the university education system in the ASEAN. Finally, they agreed that professional certification examination could serve as a standard to verify the skills of the graduates in the AEC market. To date, Singapore is the only country in ASEAN that has systematically applied professional certification examination into its education curriculum. However, some disagreed that there is 
diversity in the education system in the ASEAN education system.

Table 1. Public policies for higher education systems in 10 ASEAN associate countries.

\begin{tabular}{|c|c|c|}
\hline $\begin{array}{l}\text { ASEAN } \\
\text { Countries }\end{array}$ & Policies & Objectives \\
\hline Brunei & $\begin{array}{l}\text { The 21st National } \\
\text { Education Systems } \\
\text { (SPN 21) - 2012 }\end{array}$ & $\begin{array}{l}\text { 1. Equip students with necessary skills and knowledge that is necessary for them } \\
\text { to compete at both local and international job market. } \\
\text { 2. Gear nation towards quality education and better economic performance. }\end{array}$ \\
\hline Cambodia & $\begin{array}{l}\text { Educational } \\
\text { Strategic Plan } \\
(2006-2010)\end{array}$ & $\begin{array}{l}\text { 1. Increase opportunities of higher education among prioritized students (poor } \\
\text { students, female students, students from remote areas). } \\
\text { 2. Improve quality and efficiency of education service and institutional } \\
\text { development and capacity building. }\end{array}$ \\
\hline Indonesia & $\begin{array}{lr}\text { Higher } & \text { Education } \\
\text { Long } & \text { Term } \\
\text { Strategy } & (2003- \\
2010) & \end{array}$ & $\begin{array}{l}\text { 1. Integrate internal and external quality assurance by developing Higher } \\
\text { Education Institution (HEI) database. } \\
\text { 2. Implement new paradigm in education management and quality } \\
\text { improvement. }\end{array}$ \\
\hline Laos & $\begin{array}{l}\text { Higher Education } \\
\text { and Skills for } \\
\text { Growth in Lao PDR } \\
-2012\end{array}$ & $\begin{array}{l}\text { 1. Improve quality of higher education. } \\
\text { 2. Improve functional skills among students that are required to be employable } \\
\text { in the future. }\end{array}$ \\
\hline Malaysia & $\begin{array}{l}\text { National Education } \\
\text { Strategic Plan } \\
(\text { NHESP - 2020) }\end{array}$ & $\begin{array}{l}\text { 1. Make Malaysia a "hub of higher education excellence". } \\
\text { 2. Develop human capital with first class mentality. } \\
\text { 3. Reposition country's higher education to meet current and future challenges }\end{array}$ \\
\hline Myanmar & $\begin{array}{l}\text { Long Term } \\
\text { Education } \\
\text { Development Plan } \\
(2001-2030)\end{array}$ & $\begin{array}{l}\text { 1. Generate a learning society capable of facing the challenges of the knowledge } \\
\text { based society. } \\
\text { 2. Development of human resource, expansion of research, promotion of quality } \\
\text { education, and preservation of national identity and values. }\end{array}$ \\
\hline Philippines & $\begin{array}{l}\text { Long Term } \\
\text { Development Plan } \\
(2010-2020)\end{array}$ & $\begin{array}{l}\text { 1. Broaden the access of disadvantaged groups to higher education. } \\
\text { 2. Improve quality of HEIs, programs, and graduates to match the demands of } \\
\text { domestic and global market. } \\
\text { 3. Strengthen research activities in HEIs. } \\
\text { 4. Expand alternative learning systems/modality in higher education. }\end{array}$ \\
\hline Singapore & $\begin{array}{l}21^{\text {st }} \text { Century } \\
\text { Competencies in } \\
\text { Academic } \\
\text { Curriculum }(2012 \\
-2014)\end{array}$ & $\begin{array}{l}\text { 1. Prepare students to thrive in a fast changing and highly connected world. } \\
\text { 2. Develop civic society, global awareness, cross cultural skills, critical and } \\
\text { inventive thinking and communication skills. } \\
\text { 3. Refine teaching approaches and assessment methods. } \\
\text { 4. Develop tools for holistic feedback and assessment. }\end{array}$ \\
\hline Thailand & $\begin{array}{l}\text { Long Term Higher } \\
\text { Education Plan } \\
\text { Phase } 2(2008- \\
2022)\end{array}$ & $\begin{array}{l}\text { 1. Focus on education ethics. } \\
\text { 2. Focus on linking education with employability. } \\
\text { 3. Development of Thailand as regional hub for higher education. } \\
\text { 4. Innovation to improve national competitiveness. } \\
\text { 5. Liberalization of trade in education services to produce the future } \\
\text { employment in AEC. } \\
\text { 6. Encourage educational institutions to produce graduates of international } \\
\text { quality who are equipped with professional skills, language skills and inter- } \\
\text { cultural skills. }\end{array}$ \\
\hline Vietnam & $\begin{array}{l}\text { Education } \\
\text { Development } \\
\text { Strategy }(2008- \\
2020)\end{array}$ & $\begin{array}{l}\text { 1. Develop high quality human resource to match the socio economic structure } \\
\text { and modernization of country. } \\
\text { 2. Enhance national competitiveness in the regional economic integration. } \\
\text { 3. Focus on linking educational training with job placement and demand of } \\
\text { employability. }\end{array}$ \\
\hline
\end{tabular}

(Source: ASEAN Secretariat, 2014). 


\section{CONCLUSION}

Public policies for the higher education systems in the ASEAN countries is diverse; therefore students involved in the intra - regional movement may face many problems in terms of cultural diversity, language and communication barrier, instructional practices and curriculum incomparability. Public policies for the higher education systems in 5 ASEAN associate countries are expired and the half of them are

\section{REFERENCES}

Anonymous. (2015). Benefits of the ASEAN Economic Community - AEC, available at: http://aseanup.com/benefits-aseaneconomic-community-aec/ (accessed 14 November 2016).

ASEAN Secretariat. (1967). The ASEAN Declaration, available at: http://www.asean.org (accessed 5 November 2016).

ASEAN Secretariat. (2008). The ASEAN charter, available at: http://www.asean.org (accessed 14 November 2016).

ASEAN Secretariat. (2009). ASEAN economic community blueprint, available at: http://www.asean.org (accessed 14 November 2016).

ASEAN Secretariat. (2014). ASEAN Education Minister Meeting, available at: http://www.asean.org (accessed 14 November 2016).

Holloway, R., Daly, M., and Kong, D. (2015). Potential Implications of the ASEAN Economic Community for the Life Insurance Industry. Millman Research Report, July.

Pyakurel, S. (2014). ASEAN Economic Community and Its Effects on University Education: A Case Study of Skill Verification by the Means of Professional Certification Examination. MBA Thesis. Bangkok University, Bangkok.

Sagarik, D. and Kumari, I. (2014). Public Private Partnership for Primary Education in ASEAN. Asian Journal of Management still valid, namely Malaysia, Myanmar, Philippines, Thailand and Vietnam. Professional certification examination could serve as a standard to verify the skills of the graduates in the AEC market. To date, Singapore is the only country in ASEAN that has systematically applied professional certification examination into its education curriculum.

Sciences \& Education, Vol. 3 No. 4, October, pp. 142 - 153.

Shawyun, T. (2014). Landscape of HEI and Quality Challenges in AEC 2015. International Journal of Business and Management, Vol. II No 2, pp. 71 - 93.

Suttipun, M. (2014). The Readiness of Thai Accounting Students for the ASEAN Economic Community: An Exploratory Study. Asian Journal of Business and Accounting, Vol 7 No.2, pp. 139 - 157. 